\title{
Rat sperm enzymes during epididymal transit
}

\author{
K. Purvis, L. Cusan, H. Attramadal, A. Ege and V. Hansson \\ Institute of Pathology, Rikshospitalet, Oslo 1, Norway
}

\begin{abstract}
Summary. The activities of cAMP and cGMP phosphodiesterases (EC 3.1.4.1), adenylate cyclase (EC 4.6.1.1) and protein carboxyl-methylase (EC 2.1.1.24) were measured in the particulate and soluble $(105000 \mathrm{~g}$ supernatant) fractions of washed spermatozoa isolated from five segments of the adult rat epididymis. The activities of both phosphodiesterases decreased during epididymal transit, whereas adenylate cyclase and protein carboxyl-methylase underwent a progressive increase, the latter showing the most marked alteration. Both cAMP and cGMP phosphodiesterases as well as the adenylate cyclase were all associated primarily with the particulate fraction, and the extent to which these enzymes were associated with the membranes increased as the spermatozoa passed through the epididymis. Sperm protein carboxyl-methylase activity was, on the other hand, predominantly soluble in all segments of the epididymis. Adenylate cyclase, cAMP phosphodiesterase and protein carboxyl-methylase activities were found predominantly in the sperm tails, whereas CGMP phosphodiesterase was equally distributed between heads and tails.

These observations imply that the acknowledged increase in intracellular cAMP levels which occurs in spermatozoa during epididymal transit may be a consequence of both increased synthesis (adenylate cyclase) and reduced hydrolysis (phosphodiesterase).
\end{abstract}

\section{Introduction}

It has been known for many years that during epididymal transit, spermatozoa progressively acquire a potential for motility and a fertilizing ability (Blandau \& Rumery, 1964; Gaddum, 1968). In the rat, although the numbers of motile spermatozoa from all segments of the epididymis are very low when incubated in fluid, they exhibit increasing motility after dilution as they approach the caudal region (Hinton, Dott \& Setchell, 1979). The mechanisms underlying these alterations in potential motility are unknown, but may reflect the increase in intracellular cAMP which is known to occur in the gametes as they pass through the epididymis (Hoskins, Stephens \& Hall, 1974; Hoskins \& Casillas, 1975). The intracellular levels of cAMP are the net result of synthesis (adenylate cyclase, EC 4.6.1.1) and breakdown (cAMP phosphodiesterase, EC 3.1.4.1). In addition, spermatozoa contain an active protein carboxyl-methylase (EC 2.1.1.24), which appears to be related to sperm motility (Bouchard, Gagnon \& Bardin, 1980a; Gagnon et al., 1980) and cAMP formation (Gordeladze, Cusan, Abyholm \& Hansson, 1982). The present study was therefore designed to clarify (1) whether alterations in the activities of these sperm enzymes may occur during their passage through the epididymis; (2) whether the distributions of these enzymes between the particulate and soluble fractions of the cell alter during passage through the epididymis; and (3) what is the localization of these enzymes in relation to the head and tail regions of the spermatozoon. 


\section{Materials and Methods}

\section{Isolation of washed spermatozoa from epididymal segments}

The epididymides from four 90-day-old Sprague-Dawley rats were dissected free from fat and divided into 5 segments as illustrated in Text-fig. 1 . The pooled segments were cut into small pieces in Petri dishes containing $10 \mathrm{ml}$ sterile saline $(9 \mathrm{~g} \mathrm{NaCl} / \mathrm{l})$ and gently shaken for $5 \mathrm{~min}$. The resulting cell suspensions were carefully aspirated to avoid tissue debris, transferred to a centrifuge tube $(50 \mathrm{ml})$ and centrifuged at $80 \mathrm{~g}$ (SS34 rotor) for $10 \mathrm{~min}$. The resulting pellets were re-suspended in phosphate buffer $(0.02 \mathrm{M}, \mathrm{pH} \mathrm{6.0)}$ and diluted to a final concentration of $20-30 \times 10^{6}$ cells $/ \mathrm{ml}$ ). From each suspension, $2 \mathrm{ml}$ were carefully layered over $1 \mathrm{M}$-sucrose $(25$ $\mathrm{ml}$ ) in glass centrifuge tubes which were then centrifuged at $20000 \mathrm{~g}$ (SS34 rotor) for $30 \mathrm{~min}$. The sperm pellets were redissolved in Tris- $\mathrm{HCl}$ buffer $(10 \mathrm{~mm}, \mathrm{pH} 7.2)$ and the final concentrations adjusted to $20 \times 10^{6} \mathrm{cells} / \mathrm{ml}$ after counting (Bürker chamber).

\section{Preparation of particulate and cystolic fractions}

The washed spermatozoa from the five epididymal segments were homogenized $(2 \times 10$-sec bursts, Ultra Thurax) in $2 \mathrm{ml}$ Tris- $\mathrm{HCl}$ buffer $(10 \mathrm{mM}, \mathrm{pH} 7.2)$ and centrifuged at $105000 \mathrm{~g}$ ( Ti 50 rotor) for $60 \mathrm{~min}$. The supernatant was aspirated and the pellet resuspended in $2 \mathrm{ml}$ of the same buffer. To facilitate resuspension, the pellet was first scraped from the bottom of the centrifuge tube with a microspatula, transferred with a wash to a second glass tube and then gently sonicated (Ultrasonicator, Model W10; Heat Systems, East Mall, New York, U.S.A.) with a $2-\mathrm{mm}$ tip microprobe and a setting at 3.5 for $5 \mathrm{sec}$. The cytosol was similarly sonicated to control possible proteolysis. Aliquots of $25-50 \mu \mathrm{l}$ were removed for assay, and the enzyme activities were expressed per $10^{6}$ spermatozoa.

\section{Isolation of head and tail regions}

Washed spermatozoa isolated from both caput and cauda regions were sonicated $(2 \times 5 \mathrm{sec})$ in $1 \mathrm{ml}$ Tris- $\mathrm{HCl}$ buffer, as described above and mixed with an equal volume of $1.8 \mathrm{M}$-sucrose. Aliquots $(500 \mu \mathrm{l})$ of the sonicate were then carefully layered on the top of a sucrose gradient consisting of $2.05 \mathrm{M}$ - and $2.2 \mathrm{M}$-sucrose $(2 \mathrm{ml}$ each layer). The gradient was then centrifuged at $92000 \mathrm{~g}$ (SW60 rotor) for $1 \mathrm{~h}$. After centrifugation, two bands in addition to the pellet could be discerned: the uppermost band (at the interphase between the top layer and the $2.05 \mathrm{M}$-sucrose) consisted of sperm tails, a middle band (between the 2.05 and $2.2 \mathrm{M}$ layers) consisted of intact spermatozoa, and the pellet contained the sperm heads. The interphase containing the tails was aspirated and both this and the head fraction were diluted with $0.02 \mathrm{M}$-phosphate buffer and centrifuged at $90000 \mathrm{~g}$ ( $\mathrm{Ti} 60$ rotor) for $30 \mathrm{~min}$. The resulting pellets were resuspended in Tris- $\mathrm{HCl}$ buffer, counted and assayed. Enzyme activities were expressed per $10^{6}$ heads or tails.

\section{Enzyme assays}

$\mathrm{Mn}^{2+}$-dependent cyclase was assayed as described by Gordeladze \& Hansson (1980). Briefly, the fractions $(30 \mu \mathrm{l})$ were incubated for $20 \mathrm{~min}$ at $35^{\circ} \mathrm{C}$ with $20 \mu \mathrm{l}$ medium containing $20 \mathrm{~mm}-\mathrm{Mn}^{2+}, 1.4 \mathrm{~mm}$-EDTA, $1 \mathrm{mM}-\beta$-mercaptoethanol, $0.5 \mathrm{~mm}$-ATP (including $4.8 \times 10^{6}$ c.p.m. of $\left.\left[\alpha{ }^{-32} \mathrm{P}\right] \mathrm{ATP}\right), 1 \mathrm{mM}$-cAMP (containing 10000 c.p.m. of $\left[8-{ }^{3} \mathrm{H}\right] \mathrm{cAMP}$ ) and a regenerating system $(0.02 \mathrm{mg}$ myokinase $/ \mathrm{ml}, 0.2 \mathrm{mg}$ creatine kinase $/ \mathrm{ml}$ and $20 \mathrm{~mm}$-creatine phosphate) for ATP. The reaction was stopped by adding $100 \mu \mathrm{l}$ of a solution containing 10 mM-cAMP, $40 \mathrm{mM}$-ATP and $1 \%$ sodium dodecyl sulphate. Any [ ${ }^{32}$ P]cAMP formed was subsequently isolated by combined Dowex $50-\mathrm{X} 4$ and alumina oxide chromatography and the radioactivity was determined. 
Protein carboxy methylase was assayed by a modification of a method previously described (Gagnon et al., 1979). Enzyme activity in $20 \mu \mathrm{l}$ cytosol was measured at $35^{\circ} \mathrm{C}$ in $0.25 \mathrm{M}$-sodium acetate buffer $(10 \mu \mathrm{l}) \mathrm{pH} 5.8$, using $1.6 \mu \mathrm{M}-S$-adenosyl-L-[methyl- $\left.{ }^{3} \mathrm{H}\right]$ methionine $(10 \mu \mathrm{l})$ as methyl donor and gelatin at $10 \mathrm{mg} / \mathrm{ml}(10 \mu \mathrm{l})$ as exogenous methyl acceptor protein. After 15 min incubation, the reaction was stopped by the addition of $500 \mu \mathrm{l} 10 \%$ trichloroacetic acid and centrifuged at $4200 \mathrm{~g}$ for $20 \mathrm{~min}$; the pellet was resuspended in $200 \mu \mathrm{l} \mathrm{M}$-borate buffer, $\mathrm{pH} 10$, to release the methyl groups. The radioactive methanol was extracted with $3 \mathrm{ml}$ of a mixture of toluene-isoamyl alcohol $(3: 2 \mathrm{v} / \mathrm{v})$. Aliquots of $1 \mathrm{ml}$ were then transferred to two separate vials; one was counted by liquid scintillation spectrometry (LKB, DELTA 300) the second aliquot (blank) was evaporated for $1 \mathrm{~h}$ at $80^{\circ} \mathrm{C}$ in a chromatography oven and the radioactivity determined. The difference in radioactivity between the two vials was taken as measure of methanol formation.

The details of the assay for cAMP and cGMP phosphodiesterases have also been described elsewhere (Purvis, Olsen, Barry \& Hansson, 1981). In essence, the sperm fractions (50 $\mu$ ) were incubated at $30^{\circ} \mathrm{C}$ for $20 \mathrm{~min}$ in a Tris- $\mathrm{HCl}$ buffer $(10 \mathrm{mM}, \mathrm{pH} 7.2)$ containing calcium $(0.4$ $\mathrm{mM})$ and magnesium $(5 \mathrm{~mm})$ at a final substrate concentration of $1 \mu \mathrm{M}$ and approximately 400000 d.p.m. of $\left[{ }^{3} \mathrm{H}\right]$ cAMP of $\left[{ }^{3} \mathrm{H}\right]$ cGMP. The reaction was stopped by transferring the incubation tubes to a boiling waterbath for $2 \mathrm{~min}$. The resulting 5'AMP or 5'GMP was then converted to the corresponding nucleoside by incubation with $50 \mu \mathrm{g}$ snake venom (Crotalus atrox; Sigma Chemical Co.) for $15 \mathrm{~min}$ at $34^{\circ} \mathrm{C}$. This reaction was then terminated by the addition of excess adenosine or guanosine ( $100 \mu \mathrm{l}$ of $10 \mathrm{~mm}$ solution). The resulting nucleoside was separated from unchanged cyclic nucleotide by chromatography through small columns of Dowex (AG2 × 8, $200 \times 400$ mesh), and counted.

For all four enzymes, the results were expressed as pmol or fmol substrate hydrolysed per min per $10^{6}$ spermatozoa.

\section{Results}

\section{Sperm enzymes during epididymal transit}

The activities of all four enzymes in the spermatozoa isolated from the five epididymal segments are shown in Text-fig. 1. In the caput region the cGMP phosphodiesterase was predominantly particulate (75\%) whilst the cAMP enzyme was relatively more soluble $(57 \%)$. Thereafter, cGMP and cAMP hydrolysing capacities became reduced in the particulate and cytosolic fractions as the spermatozoa traversed the epididymis. The total phosphodiesterase activity in the caudal region was approximately $17 \%$ and $22 \%$ of that in the caput region for cGMP and cAMP, respectively. In both cases the relative proportion of particulate enzyme increased during transit up to the caudal segment where it comprised $86 \%$ and $74 \%$ of the total cGMP and cAMP hydrolysing capacity, respectively.

Protein carboxyl-methylase activity increased during epididymal transit: caudal spermatozoa exhibited approximately four times more activity (total) per $10^{6}$ cells than did cells from the caput region. The enzyme was predominantly soluble in all epididymal segments and it was this soluble form which underwent the marked increase on approach to the caudal region.

The $\mathrm{Mn}^{2+}$-dependent adenylate cyclase was predominantly particulate in all epididymal segments (92-96\%). Its activity gradually increased during transit and spermatozoa isolated from the caudal region exhibited approximately $40 \%$ more activity than those from the caput area.

\section{Localization of enzymes to head and tail regions}

Although cGMP hydrolysing activity was localized in the head and tail regions of spermatozoa from the caput and cauda epididymidis (Table 1), the cAMP hydrolysing enzyme 


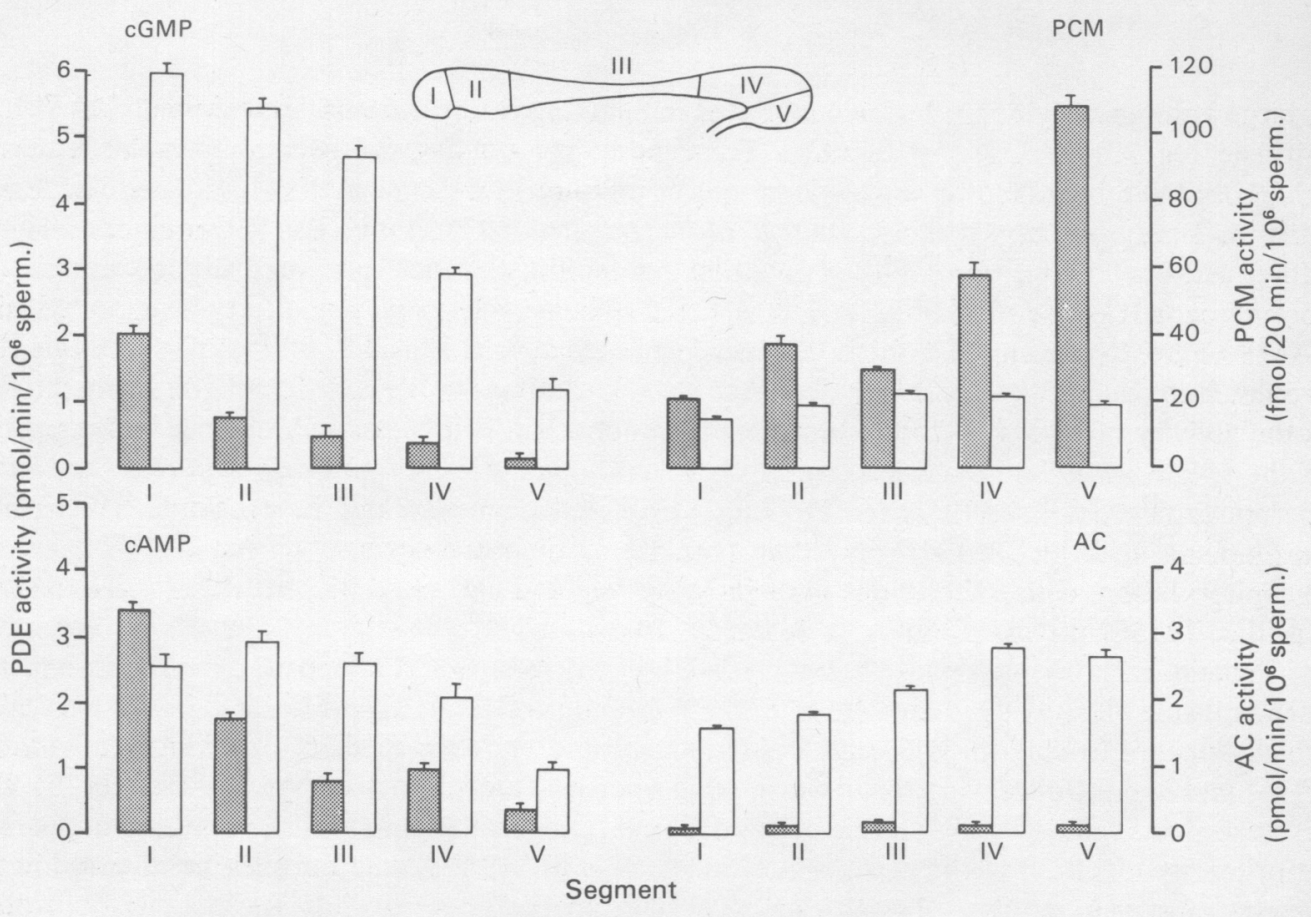

Text-fig. 1. Activities of phosphodiesterase (PDE), protein carboxyl-methylase (PCM) and adenylate cyclase (AC) in washed spermatozoa from five epididymal segments. Inset illustrates how the epididymides were divided (I, caput; V, cauda). Activities were determined in both the cytosolic (105000 g supernatant, stippled columns) and particulate fractions (105000 $\mathrm{g}$ sediment, open columns). Vertical bars represent standard deviations of triplicate measurements on each pool.

was predominantly associated with the tail region in cells isolated from both epididymal segments. Protein carboxyl-methylase activities were low since it is primarily soluble and most would have been lost during the preparation. However, the remaining activity was primarily associated with the tail region in the caput and cauda regions.

A similar distribution was found for adenylate cyclase, although significant activity was detected in heads isolated from cauda spermatozoa.

Table 1. Distribution of enzymes between head and tail regions of rat epididymal spermatozoa

\begin{tabular}{|c|c|c|c|c|c|c|c|c|}
\hline \multirow[b]{2}{*}{ Region } & \multicolumn{2}{|c|}{$\begin{array}{c}\text { cGMP } \\
\text { Phosphodiesterase }\end{array}$} & \multicolumn{2}{|c|}{$\begin{array}{c}\text { cAMP } \\
\text { Phosphodiesterase }\end{array}$} & \multicolumn{2}{|c|}{$\begin{array}{l}\text { Adenylate } \\
\text { cyclase }\end{array}$} & \multicolumn{2}{|c|}{$\begin{array}{l}\text { Protein } \\
\text { carboxyl-methylase }\end{array}$} \\
\hline & Caput & Cauda & Caput & Cauda & Caput & Cauda & Caput & Cauda \\
\hline Head & $\begin{array}{r}6.4 \\
\pm 0.2\end{array}$ & $\begin{aligned} & 2.6 \\
\pm & 0.08\end{aligned}$ & $\begin{array}{r}0.02 \\
+0.01\end{array}$ & $\begin{array}{l}0.019 \\
\pm \\
0.01\end{array}$ & $\begin{array}{r}1.5 \\
\pm 2.2\end{array}$ & $\begin{array}{l}21 \\
\pm 0.7\end{array}$ & - & 一 $^{*}$ \\
\hline Tail & $\begin{array}{r}7.5 \\
+0.3\end{array}$ & $\begin{aligned} & 3.2 \\
\pm & 0.09\end{aligned}$ & $\begin{aligned} & 10.0 \\
\pm & 0.50\end{aligned}$ & 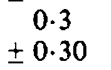 & $\begin{array}{r}45.0 \\
\pm 13.4\end{array}$ & $\begin{array}{r}112.2 \\
\pm 10.8\end{array}$ & $\begin{array}{r}37.0 \\
\pm 3.6\end{array}$ & $\begin{array}{r}72.0 \\
\pm 1.5\end{array}$ \\
\hline
\end{tabular}

Results expressed as pmol (or fmol for protein carboxyl-methylase) $/ \mathrm{min} / 10^{6}$ heads or tails, \pm standard deviation. All determinations were performed in triplicate.

* Undetectable. 


\section{Discussion}

A large volume of evidence has accumulated implicating cyclic nucleotides, especially cAMP, as intrinsic regulators of sperm motility. Thus, dibutyryl cAMP and several phosphodiesterase inhibitors have been shown to maintain sperm motility in a number of species (Garbers, Lust, First \& Lardy, 1973; Hoskins, Hall \& Munstermann, 1975; Dacheux \& Paquignon, 1980). Moreover, the acquisition of this potential for motility, which progressively occurs as the spermatozoa traverse the epididymis, is reported to be correlated with an increase in intracellular cAMP content (Hoskins, Stephens \& Hall, 1974; Hoskins \& Casillas, 1975). The results of the present study suggest that the elevated cAMP levels may be explained by a progressive reduction in the activity of cAMP phosphodiesterase in conjunction with a gradual increase in the activity of the sperm adenylate cyclase. Similar observations have been separately reported for bovine spermatozoa (Casillas, Elder \& Hoskins, 1978; Stephens, Wang \& Hoskins, 1979). The mechanisms by which cAMP may then regulate motility are not known, but cAMP may, via phosphorylation, cause alterations in respiratory rate and carbohydrate metabolism (Hoskins \& Casillas, 1975; Milkowski, Babcock \& Lardy, 1976).

Protein carboxyl-methylase transfers methyl groups from $S$-adenosyl-L-methionine to the carboxyl side chains of proteins (Liss, Maxam \& Cuprak, 1969; Morin \& Liss, 1973), a reaction which appears to play an important role in exocytotic secretion (Diliberto, Viveros \& Axelrod, 1976) and in controlling flagellar movement in bacteria (Kort, Goy, Larsen \& Adler, 1975). The testis contains relatively high levels of this enzyme (Diliberto \& Axelrod, 1976) which appears to be primarily localized in the germ cells (Bouchard et al., 1980a) where it may be involved in the genesis of sperm motility (Gagnon et al., 1980). In the present study the activity of protein carboxyl-methylase became greatly elevated as the gamete approached the cauda region where it acquires greater motility. Gagnon et al. (1980) correlated poor motility of human spermatozoa with abnormally low levels of protein carboxyl-methylase, testifying to its possible role in the maintenance of sperm movement. Interestingly, cAMP phosphodiesterase, adenylate cyclase and protein carboxyl-methylase all appear to be located in the tail region of the spermatozoon where they are presumably coupled to the locomotory apparatus. The localization of protein carboxyl-methylase to this region confirms similar observations by Bouchard, Gagnon, Phillips $\&$ Bardin (1980b).

The marked decrease in cGMP phosphodiesterase activity which also takes place during epididymal transit may serve to raise the intracellular levels of cGMP, although the function of this cyclic nucleotide is still unknown. Immunological techniques have localized cGMP to the nuclear elements of many different germ cells including the mature spermatids (Spruill \& Steiner, 1976), suggesting that it may be involved in chromosomal events. It may be relevant therefore that cGMP phosphodiesterase exhibits the greatest activity in the head region of the spermatozoon, a region which is almost devoid of cAMP hydrolysing activity. The tail region on the other hand, which appears by immunochemistry to contain high levels of cAMP (Spruill \& Steiner, 1976), also possesses the highest levels of cAMP phosphodiesterase.

As the spermatozoon traverses the epididymis the distribution of the three enzymes, between the particulate and cytosolic fractions of the cell, becomes altered to varying degrees. On entering the caput region, the cGMP phosphodiesterase and the adenylate cyclase are already, to a large extent, particulate. Within the testis, however, both of these enzymes are primarily soluble (unpublished information). Presumably this transfer of activity from one cellular compartment to other occurs relatively rapidly during the more advanced stages of spermiogenesis. With regard to the cAMP phosphodiesterase and protein carboxyl-methylase, a much higher proportion of the enzyme activity is associated with the soluble compartment of the spermatozoon on entry to the epididymis. This emphasizes that at least two isoforms of phosphodiesterase exist which are localized in different regions and in different subcellular compartments of the cell, at least at specific stages of sperm maturation. After entering the 
epididymis the cAMP phosphodiesterase progressively becomes more particulate but in all segments maintains a relatively higher soluble fraction than the cGMP isoform. The significance of these altered distributions in all four enzymes during the later stages of sperm development are unknown.

The increase in cAMP levels which occurs within the epididymis is only one of the factors which contributes to the initiation of motility. Indeed, under certain conditions cAMP levels can be raised within the cell to stimulate glucose utilization without affecting oxygen consumption or motility (Cascieri, Amann \& Hammerstedt, 1976). Other mechanisms within the gamete presumably also have to mature during epididymal passage before the cAMP signal can be coupled to the locomotory apparatus. Moreover, a key feature of the fully mature spermatozoon is not only a capacity for movement, but also for movement in a forward direction. Caput spermatozoa can be stimulated to move but their movement tends to be haphazard and unlike that of the cauda spermatozoa which move forward progressively (Hoskins \& Casillas, 1975). A glycoprotein forward motility factor which has been postulated to bind to the spermatozoa during transit through the epididymis has been isolated (Hoskins, Brandt \& Acott, 1978). The decline in phosphodiesterase activity observed in the present study may be triggered by similar factors in the epididymal fluid. Alternatively, these alterations in enzyme activities may reflect the removal of specific inhibitors. The latter is more likely in view of the positive effects of dilution of the epididymal fluid on sperm motility in the rat (Hinton et al., 1979).

The work was supported by Rockefeller Foundation, the Norwegian Medical Research Council (NAVF) and the Norwegian Cancer Society (Landsforeningen mot Kreft).

\section{References}

Blandau, R.J. \& Rumery, R.E. (1964) The relationship of swimming movements of epididymal spermatozoa to their fertilizing capacity. Fert. Steril. 15, 571-579.

Bouchard, P., Gagnon, C. \& Bardin, C.W. (1980a) Protein carboxyl methylase in rat testes and spermatozoa. In Testicular Development, Structure and Function, pp. 441-446. Eds A. Steinberger \& E. Steinberger. Raven Press, New York.

Bouchard, P., Gagnon, C., Phillips, D.M. \& Bardin, C.W. (1980b) The localisation of protein carboxylmethylase in sperm tails. J. Cell Biol. 86, 417-423.

Cascieri, M., Amann, R.P. \& Hammerstedt, R.H. (1976) Adenine nucleotide changes at initiation of bull sperm motility. J. biol. Chem. 251, 787-793.

Casillas, E.R., Elder, C.M. \& Hoskins, D.D. (1978) Adenylate cyclase activity in maturing bovine spermatozoa: Activation by GTP and polyamines. Fedn Proc. Fedn Am. Socs exp. Biol. 37, 2307.

Dacheux, J.L. \& Paquignon, M. (1980) Effects of caffeine on ram and boar spermatozoa: Influence of their stage of maturation and the medium on initiation of progressive motility of testicular spermatozoa. In Testicular Development, Structure and Function, pp. 513-522. Eds E. Steinberger \& A. Steinberger. Raven Press, New York.

Diliberto, E.J., Jr, \& Axelrod, J. (1976) Regional and subcellular distribution of protein carboxy-methylase in brain and other tissues. J. Neurochem. 26, 1159-1165.

Diliberto, E.J., Jr, Viveros, O.H. \& Axelrod, J. (1976) Subcellular distribution of protein carboxy-methylase and its endogenous substrates in the adenal medulla: possible role in excitation-secretion coupling. Proc. natn. Acad. Sci. U.S.A. 73, 4050-4054.

Gaddum, P. (1968) Sperm maturation in the male reproductive tract: Development of motility. Anat. Rec. 161, 471-482.

Gagnon, C., Axelrod, J., Musto, N., Dym, M. \& Bardin, W. (1979) Protein carboxyl methylation in rat testes: A study of inhibited and X-ray-induced seminiferous tubule failure. Endocrinology 105, 1440-1445.

Gagnon, C., Sherins, R.J., Mann, T., Bardin, C.W., Amelar, R.D. \& Dublin, L. (1980) Deficiency of protein carboxyl-methylase in spermatozoa of necrospermic patients. In Testicular Development, Structure and Function, pp. 491-495. Eds A. Steinberger \& E. Steinberger. Raven Press, New York.

Garbers, D.L., Lust, W.D., First, N.L. \& Lardy, H.A. (1973) The effects of phosphodiesterase inhibitors and cyclic nucleotides on sperm respiration and motility. Biochemistry, N.Y. 19, 1825-1831.

Gordeladze, J.O. \& Hansson, V. (1980) $\mathrm{Mn}^{2+}$-dependent adenylyl cyclase (AC) in rat testis: Kinetic properties and optimization of assay conditions. Int. J. Androl. 3, 539-552.

Gordeladze, J.O., Cusan, L., Ábyholm, T. \& Hansson, V. (1982) Adenylyl cyclase (AC) and protein carboxyl methylase (PCM) activities in human ejaculated spermatozoa. Int. J. Androl. (in press).

Hinton, B.T., Dott, H.M. \& Setchell, B.P. (1979) Measurement of the motility of rat spermatozoa collected by micropuncture from the testis and from different regions along the epididymis. J. Reprod. Fert. 55, 167-172. 
Hoskins, D.D. \& Casillas, E.R. (1975) Hormones, second messengers, and the mammalian spermatozoon. In Molecular Mechanisms of Gonadal Hormone Action, pp. 283-324. Eds J. A. Thomas \& R. L. Signal. University Park Press, Baltimore.

Hoskins, D.D., Stephens, D.T. \& Hall, M.L. (1974) Cyclic adenosine $3^{\prime}, 5^{\prime}$-monophosphate and protein kinase levels in developing bovine spermatozoa. $J$. Reprod. Fert. 37, 131-133.

Hoskins, D.D., Hall, M.L. \& Munstermann, D. (1975) Induction of motility in immature bovine spermatozoa by cyclic AMP phosphodiesterase inhibitors and seminal plasma. Biol. Reprod. 13, 168 176.

Hoskins, D.D., Brandt, H. \& Acott, T.S. (1978) Initiation of sperm motility in the mammalian epididymis. Fedn Proc. Fedn Am. Socs exp. Biol. 37, 2534-2542.

Kort, E.N., Goy, M.F., Larsen, S.H. \& Adler, J. (1975) Methylation of membrane protein involved in bacterial chemotaxis. Proc. natn. Acad. Sci. U.S.A. 72 , 3939-3943.
Liss, M., Maxam, A.M. \& Cuprak, LJ. (1969) Methylation of protein by calf spleen methylase: a new protein methylation reaction. J. biol. Chem. 244, 1617-1622.

Milkowski, A.L., Babcock, D.F. \& Lardy, H.A. (1976) Activation of bovine epididymal sperm respiration by caffeine. Archs Biochem. Biophys. 176, 250-256.

Morin, A.M. \& Liss, M. (1973) Evidence for a methylated protein intermediate in pituitary methanol formation. Biochem. Biophys. Res. Commun. 52, 373-378.

Purvis, K., Olsen, A., Barry, M. \& Hansson, V. (1981) Testicular cyclic nucleotide phosphodiesterase in the rat. Arch. Androl. 6, 327-335.

Spruill, A. \& Steiner, A. (1976) Immunohistochemical localisation of cyclic nucleotides during testicular development. J. cyclic Nucl. Res. 2, 225-239.

Stephens, D.T., Wang, J.L. \& Hoskins, D. (1979) The cyclic AMP phosphodiesterase of bovine spermatozoa: multiple forms, kinetic properties and changes during development. Biol. Reprod. 20, 483-491. 